\title{
Effect of Bacillus spp. on Gerbera plant growth and control of Meloidogyne incognita
}

\section{P. Manju* and S. Subramanian}

Department of Nematology, Tamil Nadu Agricultural University, Coimbatore - 641003 (Tamil Nadu), INDIA *Corresponding author. E-mail: agrimanju@gmail.com

Received: November 18, 2016; Revised received: March 31, 2017; Accepted: August 9, 2017

\begin{abstract}
A greenhouse experiment was conducted to evaluate the efficacy of Bacillus spp. against Meloidogyne incognita (Kofoid and White) Chitwood infesting gerbera plants (Var. Valletta). Investigations were undertaken in pots filled with $5 \mathrm{~kg}$ of sterilized potting mixture consisting of red soil:sand:FYM $(2: 1: 1 \mathrm{v} / \mathrm{v})$ to assess the effect of liquid and talc formulations of $B a$ cillus spp. viz., B. subtilis strain BG42, B. subtilis strain BG37 and B. amyloliquefaciens strain B4. The results indicated that Soil drenching of liquid formulation of $B$. subtilis strain BG42@1\%/ $\mathrm{m}^{2}\left(1 \times 10^{8}\right.$ colony forming units/g) gave maximum reduction of juveniles per $250 \mathrm{~g}$ soil $(67.40 \%)$, number of adult females $/ 5 \mathrm{~g}$ root $(73.46 \%)$, number of eggmass $/ 5 \mathrm{~g}$ root $(69.44 \%)$, gall index (1.67) and increased flower yield $/ \mathrm{m}^{2}$ (127.03\%). Soil drenching of liquid formulation of $B$. subtilis strain BG 37 were next in line in efficacy. Further liquid formulation of $B$. subtilis strain BG42 had a positive influence on growth parameters viz., shoot length, root length, shoot and root weight, number of leaves / plant and flower yield $/ \mathrm{m}^{2}$ and quality parameters viz., flower diameter, colour of the flower, length of flower stalk and vase life. The endophytic colonization potential of the Bacillus spp. introduced into the soil was confirmed by re-isolating them from gerbera roots.
\end{abstract}

Keywords: Bacillus amyloliquefaciens, Bacillus subtilis, Biocontrol, Gerbera jamesonii, Meloidogyne incognita

\section{INTRODUCTION}

Gerbera (Gerbera jamesonii Hook) belongs to the Asteraceae family, which is a perennial Mediterranean plant. Gerbera popularly known as Transvaal daisy, is one of the ten most popular commercial cut flowers in the world and according to the global trends in floriculture, it occupies the fourth place among cut flowers (Choudhary and Prasad, 2000). The tremendous variability in gerbera with reference to flower colour, shape and size makes it more useful for cut flowers, bouquet, decoration in marriages and landscaping in gardening (Aswath and Survay, 2004). It is inconsiderable demand in both domestic and export markets.

Of the several limiting factors that cause serious concern to commercial production, plant parasitic nematodes are most important. Although a multitude of plant parasitic nematodes are found associated with carnation and gerbera elsewhere in the world (Lamberti et al., 1987), root knot nematodes belonging to Meloidogyne spp. are predominant in India (Nagesh and Parvath Reddy, 2001). Exotic varieties of these plants from Europe suffered $40-60 \%$ mortality due to Root knot nematode infection and its interaction with other soil-borne pathogens (Nagesh and Parvatha Reddy, 1996). In India, yield losses due to $M$. incognita in carnation and gerbera were estimated to the tune of 26.6 and 31.1 per cent, respectively (Nagesh and Parvatha Reddy, 2000).

Several control strategies, such as host plant resistance, rotation with non-hosts, sanitation and avoidance, destruction of residual crop roots, and judicious use of nematicides, have been reported to effectively control root knot nematodes (Whitehead, 1998). Due to environmental concerns and increased regulations on use of chemical fumigants, more management strategies for management of root knot nematodes investigated (Nico et al., 2004). Biological control using microbial antagonists is one potential alternative to chemical nematicides.

Rhizosphere microorganism includes some bacteria and fungi may provide defense against pathogen attack (Weller 1988). The rhizoplane and rhizosphere are colonized or otherwise occupied by many microorganisms. Plant growth promoting bacteria produce plant growth promoting substances and antibi-otics. They are capable of providing substantial protec-tion against nematode diseases (Siddiqui and Mahmood 1999).

Among the plant growth-promoting rhizobacteria (PGPR), Pseudomonas and Bacillus are the genera most commonly described as having PGPR but many other taxa also contain PGPR (Barea et al., 2005).

Several Bacillus species such as B. cereus, B. subtilis, $B$. nematocida, $B$. firmus, $B$. thuringiensis and $B$. megaterium (Oka et al., 1993; Krebs et al., 1998; Siddiqui, 2002; Wei et al., 2003; Niu et al., 2007; Karanja et al., 2007; Mendoza et al., 2008; Salehi jouzani et al., 2008; Terefe et al., 2009; Huang et al., 2009; Xia et al., 2011; Khalil et al., 2012) have been shown to effectively control Meloidogyne species. 
Now-a-days the use of bioagents (Bacillus spp.) are considered as one of the alternative approaches for the management of nematodes as it is safe to environment, no health hazards to human beings, economic and easily available to farmers in comparison to chemicals. Therefore, an attempt was made to evaluate the talc and liquid formation of Bacillus spp. as soil application and soil drenching against $M$. incognita in gerbera.

\section{MATERIALS AND METHODS}

Greenhouse experiment was conducted at the Department of Nematology, Tamil Nadu Agricultural University, Coimbatore during 2014-2015 with the following treatments: T1- Soil drenching of liquid formulation of B. subtilis BG42@1\%/m ; T2: Soil application of talc formulation of B. subtilis BG42@1\%/m²; T3 : Soil drenching of liquid formulation of B. subtilis BG37@1\%/m² T4 : Soil application of talc formulation of B. subtilis BG37@1\%/m²; T5 : Soil drenching of liquid formulation of B. amyloliquefaciens B4 (a) $1 \% / \mathrm{m}^{2}$; T6 : Soil application of talc formulation of B. amyloliquefaciens B4@1\%/m²; T7- Soil application of Carbofuran $\left(3.3 \mathrm{~g} / \mathrm{m}^{2}\right)$ and T8-Untreated control. Isolation of Bacillus spp. from gerbera Rhizosphere: Ten isolates of Bacillus spp. were isolated from gerbera rhizosphere from Tamil Nadu districts namely Coimbatore, The Nilgiris, Salem and Krishnagiri. Bio efficacy of Bacillus isolates was assayed against root knot nematode by hatching and mortality tests. Among the ten isolates screened, highest inhibition in egg hatching and highest per cent mortality of M. incognita juveniles was observed at Bacillus isolate BG42 followed by BG37. The partial $16 \mathrm{~S}$ rDNA sequences of the isolated strains BG37 and BG42 showed $99 \%$ identity with Bacillus subtilis and were deposited in GenBank under accession numbers KM454178 and KM588210 respectively. Existing strain B. amyloliquefaciens B4 reported to be effective against plant pathogens was obtained from the Centre for Plant Protection studies, Department of plant

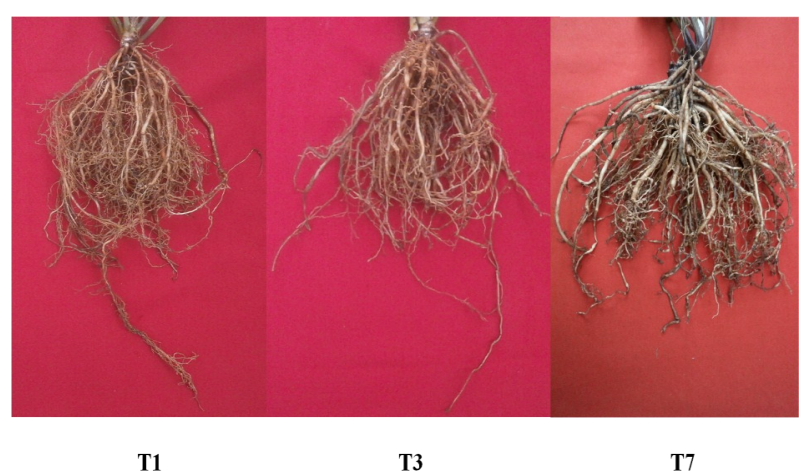

Fig. 1. Variation in root growth of gerbera treated with different Bacillus spp. under controlled conditions(T1 - Liquid formulation of B. subtilis strain BG42; T3 - Liquid formulation of B. subtilis strain BG37; T7 - Untreated control). pathology, Tamil Nadu Agricultural University, Coimbatore.

Development of formulations of the antagonistic Bacillus spp. for greenhouse application

Bacillus spp. liquid formulation: The Bacillus strains were grown in the nutrient broth with constant shaking at $150 \mathrm{rpm}$ for $48 \mathrm{~h}$ at room temperature $\left(28 \pm 2^{\circ} \mathrm{C}\right)$. The bacterial cells were harvested and centrifuged at 6000 rpm for $15 \mathrm{~min}$ and the cells were resuspended in phosphate buffer $(0.01 \mathrm{M}, \mathrm{pH} 7.0)$. The concentration was adjusted using a spectrophotometer to approximately $10^{8} \mathrm{cfu} / \mathrm{ml}\left(\mathrm{OD}_{595}=0.3\right)$ and used as bacterial inoculum. These strains were kept at $-80^{\circ} \mathrm{C}$ in 44 per cent glycerol and cells from stock were first grown in NA broth. Inoculum was prepared by transferring one loopful from each culture to $100 \mathrm{ml}$ of NA broth in a $250 \mathrm{ml}$ conical flask and incubated at room temperature $\left(28 \pm 2^{\circ} \mathrm{C}\right)$ on a shaker at $150 \mathrm{rpm}$ for $48 \mathrm{hr}$.

Bacillus spp. talc formulation: A loopful of Bacillus isolates were inoculated into nutrient broth separately and incubated in a rotary shaker at $150 \mathrm{rpm}$ for $48 \mathrm{~h}$ at room temperature $\left(28+2^{\circ} \mathrm{C}\right)$. The broth containing $9 \mathrm{x}$ $10^{8} \mathrm{cfu} / \mathrm{ml}$ was used for the preparation of talc based formulations. To $400 \mathrm{ml}$ of bacterial suspension, one $\mathrm{kg}$ of the purified talc powder (sterilized at $105^{\circ} \mathrm{C}$ for $12 \mathrm{~h}$ ), $15 \mathrm{~g}$ of calcium carbonate (to adjust the $\mathrm{pH}$ to neutral) and $10 \mathrm{~g}$ of carboxy methyl cellulose (CMC) as an adhesive were mixed under aseptic conditions following the method described by Vidhyasekaran and Muthamilan (1999). The product was shade dried to reduce the moisture content to less than 20 per cent and then packed in polypropylene bags and sealed. At the time of application, the population of bacteria in talc formulation was assessed as $1 \times 10^{8} \mathrm{cfu} / \mathrm{g}$.

Greenhouse experiment: Earthen pots of $30 \times 20 \times 18$ $\mathrm{cm}$ size filled with $5 \mathrm{~kg}$ sterilized pot mixture containing red soil:sand:FYM, 2:1:1 (v/v). The tissue culture derived 35 days old gerbera var. Valletta seedlings were planted in the above pots at the rate of one plant / pot. After establishment of the seedlings the Bacillus spp. were applied as scheduled. Simultaneously, second stage juveniles of $M$. incognita were inoculated into the pots at the root zone of gerbera (one juvenile per $g$ soil) by making three holes around the plant and covered with sterilized soil. Each treatment was replicated three times and pots arranged in a completely randomized block design. Regular watering was done with tap water passed through 325 mesh sieve.

The crop was maintained by applying recommended dosages of fertilizers and plant protection chemicals. No pest or disease was recorded during the study. Emerging flowers were picked at regular intervals and flower yield recorded. The experiment was terminated 180 days after planting (DAP). The plants were carefully depotted and observation on plant growth parameters viz., shoot length, root length, shoot and root weight and number of leaves / plant quality parameters viz., 
flower diameter, colour of the flower, length of flower stalk and vase life and nematode incidence in terms of number of egg masses per $5 \mathrm{~g}$ root, eggs per egg mass, adult females per $5 \mathrm{~g}$ root, final soil nematode population and gall index were recorded.

Diameter of flower was recorded at full bloom stage. The readings were taken from each flower, and then average was worked out and expressed in centimeters. The colours of the disc floret was noted by visual observation and rated 1-3 scale as 1 - Very good; 2 Good; 3 - Satisfactory. The length of flower stalk was measured from the point just below the flower head up to point of origin of stem and then average of stem in each treatment was worked out and expressed in centimeters. The vase life was expressed in terms of days from the date of harvest to final observation. To determine the gerbera flower vase life, the flowers soon after harvesting were kept in distilled water. Later these flowers stalks were cut to have uniform stalk length. After that flowers were kept individually in flask containing $250 \mathrm{ml}$ of distilled water. Flowers were observed daily and discarded when they were found to be unfit for containing in vase.

Regarding nematode incidence five gram of roots randomly taken from each plant and it was stained using acid fuchsin-lactophenol and number of females per gram of root observed. To count the egg masses, it were stained by dipping the roots for 15 minutes in an aqueous solution of phloxine $\mathrm{B}(0.15 \mathrm{gm} / \mathrm{L}$ water $)$ and then washed with running tap water to remove excess stain (Holbrook et al., 1983). Soil from pots were thoroughly mixed and $\mathbf{J} 2$ population density was assessed from $250 \mathrm{~g}$ of sub samples by Cobbs decanting and sieving technique followed by modified Baermann's funnel technique (Southey, 1986). Root knot index were recorded on 1-5 scale on the basis of number of galls per root system (Taylor and Sasser, 1978) and graded from 0 to $5(0=$ no galls, $1=1-2$ galls; $2=3-$ 10 galls, $3=11-30$ galls, $4=31-100$ galls, and $5=$ $>100$ galls)

To assess the root colonization of introduced Bacillus spp., one gram of root was taken at random from each plant, crushed in a sterile pestle and mortar, serial dilutions were made in sterile distilled water and plating was done on Nutrient agar medium. After incubation at $28+2^{\circ} \mathrm{C}$ for 3 days the Bacillus spp. colonies (Bacillus colonies that are opaque, wrinkled and cream in colour) were counted. Data of the present study were subjected to the analy-sis of variance test (ANOVA) as complete randomized de-sign (CRD), for greenhouse experiment.

\section{RESULTS AND DISCUSSION}

Biological control through the use of antagonistic microorganisms plays a key role in modern agriculture as it is economical and ecofriendly. Such management strategy would help in preventing the pollution and also health hazards. So in the present investigation an attempt has been made to evaluate the effect of bioagents on gerbera root knot nematode management.

Results of the study revealed that among all the treatments the liquid formulation of B. subtilis strain BG42 showed a significant increase in plant growth parameters expressed in terms of shoot length $(44.72 \mathrm{~cm})$, root length $(34.98 \mathrm{~cm})$ and shoot weight (287.45 g) (Fig 1). On the other hand a decrease in root weight $(86.35 \mathrm{~g})$ in this treatment followed by other treatments over control $(187.85 \mathrm{~g})$ was recorded which might be due to

Table 1. Efficacy of talc and liquid formulations of Bacillus isolates on M. incognita infestation in gerbera var. Valletta in pot culture studies.

\begin{tabular}{|c|c|c|c|c|c|c|}
\hline Treatment & $\begin{array}{l}\text { No. of } \\
\text { females } / 5 \mathrm{~g} \\
\text { root }\end{array}$ & $\begin{array}{l}\text { No. of egg } \\
\text { masses } / 5 g \\
\text { root }\end{array}$ & $\begin{array}{l}\text { Nematode } \\
\text { population/ } \\
\mathbf{2 5 0} \text { g of soil }\end{array}$ & $\begin{array}{l}\text { Root } \\
\text { knot } \\
\text { index } \\
\end{array}$ & $\begin{array}{l}\text { Colony form- } \\
\text { ing units(per } \\
\text { g soil) } 1 \times 10^{8}\end{array}$ & $\begin{array}{l}\text { Flower } \\
\text { yield } / \mathbf{m}^{2}\end{array}$ \\
\hline $\begin{array}{l}\text { Soil drenching of liquid formulation of } \\
\text { B. subtilis strain BG42 @ } 1 \% / \mathrm{m}^{2}\end{array}$ & $\begin{array}{l}14.33 \\
(73.46)\end{array}$ & $\begin{array}{l}11.00 \\
(69.44)\end{array}$ & $\begin{array}{l}186.67 \\
(67.40)\end{array}$ & 1.67 & $82.32 \times 10^{8}$ & $\begin{array}{l}84.00 \\
(127.03)\end{array}$ \\
\hline $\begin{array}{l}\text { Soil application of talc formulation of } \\
\text { B. subtilis } \text { strain BG42@ } 1 \% / \mathrm{m}^{2}\end{array}$ & $\begin{array}{l}16.67 \\
(69.13)\end{array}$ & $\begin{array}{l}13.67 \\
(62.03)\end{array}$ & $\begin{array}{l}199.33 \\
(65.19)\end{array}$ & 3.00 & $70.64 \times 10^{8}$ & $\begin{array}{l}75.00 \\
(102.70)\end{array}$ \\
\hline $\begin{array}{l}\text { Soil drenching of liquid formulation of } \\
\text { B. subtilis strain BG37@1\%/m }\end{array}$ & $\begin{array}{l}14.67 \\
(72.83)\end{array}$ & $\begin{array}{l}13.00 \\
(63.89)\end{array}$ & $\begin{array}{l}194.33 \\
(66.06)\end{array}$ & 2.33 & $78.43 \times 10^{8}$ & $\begin{array}{l}79.00 \\
(102.70)\end{array}$ \\
\hline $\begin{array}{l}\text { Soil application of talc formulation of } \\
\text { B. subtilis } \text { strain BG37@ } 1 \% / \mathrm{m}^{2}\end{array}$ & $\begin{array}{l}17.33 \\
(67.90)\end{array}$ & $\begin{array}{l}15.67 \\
(56.47)\end{array}$ & $\begin{array}{l}206.00 \\
(64.03)\end{array}$ & 3.33 & $66.98 \times 10^{8}$ & $\begin{array}{l}68.50 \\
(83.78)\end{array}$ \\
\hline $\begin{array}{l}\text { Soil drenching of liquid formulation of } \\
\text { B. amyloliquefaciens strain B4 @ } 1 \% / \mathrm{m}^{2}\end{array}$ & $\begin{array}{l}34.00 \\
(37.04)\end{array}$ & $\begin{array}{l}28.67 \\
(20.36)\end{array}$ & $\begin{array}{l}271.67 \\
(52.56)\end{array}$ & 3.33 & $62.41 \times 10^{8}$ & $\begin{array}{l}64.00 \\
(72.97)\end{array}$ \\
\hline $\begin{array}{l}\text { Soil application of talc formulation of } \\
\text { B. amyloliquefaciens strain B4 @ } 1 \% / \mathrm{m}^{2}\end{array}$ & $\begin{array}{l}39.33 \\
(27.17)\end{array}$ & $\begin{array}{l}29.67 \\
(17.58)\end{array}$ & $\begin{array}{l}292.00 \\
(49.01)\end{array}$ & 4.33 & $57.10 \times 10^{8}$ & $\begin{array}{l}53.00 \\
(43.24)\end{array}$ \\
\hline $\begin{array}{l}\text { Soil application of Carbofuran@3.3g/ } \\
\mathrm{m}^{2}\end{array}$ & $\begin{array}{l}39.67 \\
(26.54)\end{array}$ & $\begin{array}{l}29.33 \\
(18.53)\end{array}$ & $\begin{array}{l}282.00 \\
(50.76)\end{array}$ & 3.67 & -- & $\begin{array}{l}49.50 \\
(32.43)\end{array}$ \\
\hline Untreated control & 54.00 & 36.00 & 572.67 & 5.00 & -- & 37 \\
\hline SEd & 1.32 & 1.03 & 4.07 & & -- & 1.51 \\
\hline $\mathrm{CD}(\mathrm{p}=0.05)$ & 2.80 & 2.18 & 8.63 & -- & & 3.28 \\
\hline
\end{tabular}

Figures in parentheses are per cent decrease over control. 
reduction in formation of galls which contribute for the root weight. The second best treatment was application of liquid formulation of B. subtilis strain BG37 followed by talc formulation of $B$. subtilis strain BG42 (Table 1).

The mechanism involved in the PGPR mediated plant growth promotion are directly related to the production of plant growth regulators viz., auxin, gibberellin and cytokinin or indirectly by stimulating nutrient uptake (Dangar and Basu, 1987; Dobbelaere et al., 2003 and Dey et al., 2004) . Broadbent et al. (1977) reported the use of $B$. subtilis may also improve plant growth by suppressing non parasitic root pathogen or by the production of biologically active substances or by unavailable mineral and organic compounds into forms available to plants. Jonathan et al. (2000 and 2004) observed that $P$. fluorescens and B. subtilis were reported to induce profuse root development in banana, tomato and betelvine and reduce the infestation of $M$. incognita. Siddiqui and Mahmood (1993) also reported that B. subtilis improved plant growth system of chickpea.

In respect of quality parameters significant differences were observed among the talc and liquid formulations of Bacillus isolates. Flower stalk length was more in the application of liquid formulation of B. subtilis

Table 2. Efficacy of talc and liquid formulations of Bacillus isolates on growth of gerbera var. Valletta infested with M. incognita juveniles in pot culture studies.

\begin{tabular}{llllllll}
\hline Treatment & $\begin{array}{l}\text { Shoot } \\
\text { length } \\
\text { (cm) }\end{array}$ & $\begin{array}{l}\text { Root } \\
\text { length } \\
\text { (cm) }\end{array}$ & $\begin{array}{l}\text { Shoot } \\
\text { weight } \\
\text { (Fresh)g }\end{array}$ & $\begin{array}{l}\text { Root } \\
\text { weight } \\
\text { (Fresh) g }\end{array}$ & $\begin{array}{l}\text { Shoot } \\
\text { weight } \\
\text { (Dry)g }\end{array}$ & $\begin{array}{l}\text { Root } \\
\text { weight } \\
\text { (Dry) g }\end{array}$ & $\begin{array}{l}\text { No. } \\
\text { leaves } \\
\text { plant }\end{array}$ \\
\hline Soil drenching of liquid formulation of & 44.72 & 34.48 & 287.45 & 86.35 & 4.43 & 1.71 & 14.67 \\
/
\end{tabular}

Figures in parentheses are per cent decrease or increase over control.

Table 3. Efficacy of talc and liquid formulations of Bacillus isolates on quality parameters of gerbera var. Valletta infested with M. incognita juveniles under greenhouse conditions.

\begin{tabular}{|c|c|c|c|c|}
\hline Treatment & $\begin{array}{l}\text { Stalk length } \\
\text { (cm) }\end{array}$ & $\begin{array}{l}\text { Flower diame- } \\
\text { ter }(\mathrm{cm})\end{array}$ & $\begin{array}{l}\text { Colour and } \\
\text { Visual grade* }\end{array}$ & $\begin{array}{l}\text { Shelf life of flower } \\
\text { (No. of days) }\end{array}$ \\
\hline $\begin{array}{l}\text { Soil drenching of liquid formulation of } \\
\text { B. subtilis strain BG42 @ } 1 \% / \mathrm{m}^{2}\end{array}$ & $\begin{array}{l}58.21 \\
(48.84)\end{array}$ & $\begin{array}{l}11.03 \\
(75.08)\end{array}$ & 1 & $\begin{array}{l}11.67 \\
(40.10)\end{array}$ \\
\hline $\begin{array}{l}\text { Soil application of talc formulation of } \\
\text { B. subtilis strain BG42 @ } 1 \% / \mathrm{m}^{2}\end{array}$ & $\begin{array}{l}56.63 \\
(44.80)\end{array}$ & $\begin{array}{l}9.17 \\
(45.56)\end{array}$ & 1 & $\begin{array}{l}10.33 \\
(24.01)\end{array}$ \\
\hline $\begin{array}{l}\text { Soil drenching of liquid formulation of } \\
\text { B. subtilis strain BG37@ } 1 \% / \mathrm{m}^{2}\end{array}$ & $\begin{array}{l}57.79 \\
(47.76)\end{array}$ & $\begin{array}{l}10.03 \\
(59.21)\end{array}$ & 1 & $\begin{array}{l}11.00 \\
(32.05)\end{array}$ \\
\hline $\begin{array}{l}\text { Soil application of talc formulation of } \\
\text { B. subtilis strain BG37 @ } 1 \% / \mathrm{m}^{2}\end{array}$ & $\begin{array}{l}54.59 \\
(39.58)\end{array}$ & $\begin{array}{l}8.57 \\
(36.03)\end{array}$ & 1 & $\begin{array}{l}10.00 \\
(20.05)\end{array}$ \\
\hline $\begin{array}{l}\text { Soil drenching of liquid formulation of } \\
\text { B. amyloliquefaciens strain B4 } @ 1 \% / \mathrm{m}^{2}\end{array}$ & $\begin{array}{l}50.83 \\
(29.97)\end{array}$ & $\begin{array}{l}8.17 \\
(29.68)\end{array}$ & 2 & $\begin{array}{l}9.67 \\
(16.09)\end{array}$ \\
\hline $\begin{array}{l}\text { Soil application of talc formulation of } \\
\text { B. amyloliquefaciens strain B } 4 @ 1 \% / \mathrm{m}^{2}\end{array}$ & $\begin{array}{l}47.26 \\
(20.84)\end{array}$ & $\begin{array}{l}7.80 \\
(23.81)\end{array}$ & 2 & $\begin{array}{l}9.33 \\
(12.00)\end{array}$ \\
\hline Soil application of Carbofuran @3.3g/m & $\begin{array}{l}47.50 \\
(21.45)\end{array}$ & $\begin{array}{l}7.10 \\
(12.70)\end{array}$ & 2 & $\begin{array}{l}9.67 \\
(16.09)\end{array}$ \\
\hline Untreated control & 39.11 & 6.30 & 3 & 8.33 \\
\hline SEd & 3.54 & 0.37 & - & 0.76 \\
\hline $\mathrm{CD}(\mathrm{p}=0.05)$ & 7.56 & 0.78 & - & 1.62 \\
\hline
\end{tabular}

Figures in parentheses are per cent increase over control, *Colour and visual grade:1-Very good; 2-Good and 3-Satisfactory 
strain BG42 which recorded the stalk length of 58.21 $\mathrm{cm}$ which was 48.84 per cent increase over control followed by the application of liquid formulation of $B$. subtilis strain BG37 which showed the stalk length of $57.79 \mathrm{~cm}$. There was a significant variation in flower size and diameter in liquid formulation of $B$. subtilis strain BG42. The flower diameter was $11.03 \mathrm{~cm}$ which recorded 75.03 per cent increase over control, followed by the application of liquid formulation of B. subtilis strain BG37 which showed the flower diameter of $10.03 \mathrm{~cm}$ (Table 2).

Vase life parameter varied significantly among the treatments. The application of liquid formulation of $B$. subtilis strain BG42 extended its vase life upto 11.67 days. This recorded 40.10 per cent increase over control, followed by the application of liquid formulation of B. subtilis strain BG37 with the vase shelf life of 11 days. Untreated control flowers recorded the shelf life of 8.33 days. Manual grading on gerbera was rated as 1 -3 by visual grading. The grade I was given to the flowers treated with liquid and talc formulations of $B$. subtilis strain BG42 and B. subtilis strain BG37. Least grade of 3 was given to control. These results are in agreement with the findings Ardhanareeswaran (2012) who has observed the reduction in the population of $M$. incognita and increase in plant growth parameters viz., shoot length, root length, shoot weight, root weight and number of leaves, quality parameters such as stalk length, flower diameter, colour and shelf life in gerbera due to combined application of talc formulation of $P$. fluorescens strain Pfbv $22+$ B. subtilis Bbv 57 at 2.5 $\mathrm{kg} / \mathrm{ha}$.

The data present in Table 3 indicated that application of all the treatments reduced the $M$. incognita population density in soil, infestation in roots and root gall development compared to untreated control. Liquid formulation of Bacillus subtilis BG42@1\%/m² was most effective in controlling $M$. incognita. It reduced nematode population in soil by $67.40 \%$ and was significantly superior to other treatments. This might be due to the production of toxic metabolites like lipopeptides, iturins, surfactins, bacillomycin D and fengycins, which are secondary metabolites mainly with antifungal activity (Chen et al., 2006). Surfactin is capable of inhibiting the growth of plant pathogens (Singh and Cameotra, 2004). Joshi and Gardener (2006) observed that genes encoding surfactin and iturin synthesis are common to numerous antagonistic Bacillus spp. used as commercial biopesticide and have a pronounced capability to suppress soil borne pathogens. It was followed by Liquid formulation of Bacillus subtilis BG37, Talc formulation of Bacillus subtilis BG42, talc formulation of Bacillus subtilis BG37, Liquid formulation of Bacillus subtilis B4, talc formulation of Bacillus subtilis $\mathrm{B} 4$, carbofuran and control respectively. A significant reduction in number of adult females was observed in the liquid formulation of BG42 (14.33/ $5 \mathrm{~g}$ root). The number of egg masses is also found to be significantly reduced (11/5 g root) in the application of liquid formulation of $B$. subtilis strain BG42 which showed in 69.44 per cent reduction of $M$. incognita egg masses over the untreated control. Soil drenching of liquid formulation of B. subtilis strain BG 37 is the next best treatment in reducing the number of egg masses which accounted for 63.89 per cent reduction over untreated control.

A significant reduction of gall index was observed in liquid formulation of B. subtilis strain BG42 (1.67), compared to other treatments. The liquid formulation of B. subtilis strain BG37 treated plants is the next best treatment in reducing the gall index which recorded a value of 2.33. Siddiqui (2000) suggested that rhizobacteria and $B$. subtilis not only enhance plant growth but also suppress root knot infection and nematode density in the soil. The reduction of plant parasitic nematodes associated with $B$. subtilis may be attributed to diverse mechanisms which involve phytohormones production, mineral solubilisation, reduction of the activity of egg hatching factors, alteration of root exudates and inhibition of nematode penetration into the roots as well as reducing galling (Karanja et al., 2007).

All the biocontrol agents applied to the soil were reisolated from gerbera roots on 180 DAP. The results revealed that among the talc and liquid formulations of Bacillus isolates evaluated, the root colonization was higher $\left(82.32 \times 10^{8} \mathrm{cfu} / \mathrm{g}\right)$ in liquid formulation of $\mathrm{Ba}$ cillus subtilis strain BG42 followed by Liquid formulation of Bacillus subtilis strain BG37 (78.43 x $10^{8} \mathrm{cfu} /$ g) and talc formulation of Bacillus subtilis strain BG42 $\left(70.64 \times 10^{8} \mathrm{cfu} / \mathrm{g}\right)$ treated gerbera plants. Root colonization depends on the environmental factors, bacterial characteristics and plant exudates (Benizri et al., 2001).

Soil drenching of liquid formulation of B. subtilis strain BG42 resulted in a significant increase in the flower yield which recorded $84 \mathrm{nos} / \mathrm{m}^{2}$ with 127.03 per cent increase over the control. This was followed by a yield of $79 \mathrm{nos} / \mathrm{m}^{2}$ in the liquid formulation of $B$. subtilis strain BG37 treated plants. Flower yield recorded in control plots were $37 \mathrm{nos} / \mathrm{m}^{2}$. The results revealed that among the talc and liquid formulations of Bacillus isolates evaluated, Liquid formulation of Bacillus subtilis BG42@1\%/m² was the most effective in controlling $M$. incognita on gerbera followed by Liquid formulation of Bacillus subtilis BG37@1\%/m² and carbofuran were least effective against $M$. incognita on gerbera.

Soil drenching of liquid formulation of $B$. subtilis strain BG42 not only controlled root knot nematode, but also promoted plant growth and flower yield. This gives them an advantage over the use of chemical nematicides against root knot nematode management. 
Effective root colonization is a pre-requisite attribute for the success of liquid formulation of $B$. subtilis strain BG42 in gerbera plant growth and flower yield.

\section{Conclusion}

The results presented through this manuscript suggested that the utilization of liquid formulation of $B . s u b$ tilis strain BG42 for the control of Meloidogyne incognita is a promising strategy for the management of the nematodes. This affirmation is supported by the fact that all tested Bacillus spp. isolates, reduced the nematode severity on the plants. Such reduction was evident due to the decrease in the number of root gall formation and de abolishment of the presence of severe symptoms on the gerbera plant. Under the green house conditions, liquid formulation of $B$. subtilis strain BG42 can be considered for a next level of evaluation as a promising isolate due to its good performance in terms of colonization, plant growth promotion, flower yield and the reduction of the $M$. incognita population.

\section{ACKNOWLEDGEMENTS}

The financial assistance provided by Department of Science and Technology (DST), Government of India, New Delhi, in the form of INSPIRE Fellowship to carry out this research work is greatly acknowledged.

\section{REFERENCES}

Ardhanareeswaran, N. 2012. Evaluation of talc and liquid formulations of rhizobacteria for the management of major nematodes associated with cutflowers. M.Sc. Thesis, Tamil Nadu Agricultural University, Coimbatore, Tamil Nadu, India.

Aswath, C. and Survay Nazneen, 2004. An improved method for in vitro propagatin of gerbera. J. Orna.Horti., 7 (2): 141-146.

Barea, J. M., Pozo, M. J., Azcon, R. and Azcon, A. C. 2005. Microbial cooperation in the rhizosphere. J. Exp. Bot., 56(417): 1761-1778.

Benizri, E., Baudoin, E., and Guckert, A. 2001. Root colonization by inoculated plant growth-promoting rhizobacteria. Biocontrol Sci Technol., 11: 557-574.

Broadbent, P., Bake, K. F., Franks, N. and Holland, J. 1977. Effect of Bacillus sp. on increased growth of seedlings in steamed and in non treated soil. Phytopathol., 67: $1027-1034$.

Chen, X. H., Vater, J., Piel, J., Franke, P., Scholz, R., Schneider, K., Koumoutsi, A., Hitzeroth, G., Grammel, N., Strittmatter, A. W., Gottschalk, G., Sussmuth, R. D. and Borriss, R. 2006. Structural and functional characterization of three polyketide synthase gene clusters in Bacillus amyloliquefaciens FZB 42. J. Bact., 188: 4024 -4036 .

Choudhary, M. L. and Prasad, K. V. 2000. Protected cultivation of ornamental crops - An insight. Indian Hort. 45 (1): 49-53

Dangar, T. K. and Basu, P. S. 1987. Studies on plant growth substances, IAA metabolism and nitrogenase activity in root nodules of Phaseolus aureus Roxb. Var. mungo. Bioloica plantarum, 29: 350-354.
Dey, R. Pal, K. K., Bhatt, D. M. and Chauhan, S. M. 2004. Growth promotion and yield enhancement of peanut (Arachis hypogaea L.) by application of plant growth promoting rhizobacteria. Microbiol. Res., 159:371-394.

Dobbelaere, S. Vanderleyden, J. and Okon, Y. 2003. Plant growth promoting effects of diazotrophs in the rhizosphere. Crit. Rev. Plant. Sci., 22: 107-14.

Holbrook C. C., Knauft D. A. and Dikson D. W. 1983. A technique for screening peanut for resistance to Meloidogyne arenaria. Plant. Dis. 57: 957-958.

Huang, Y., Xu, C., Ma, L., Zhang, K., Duan, C. and Mo, M. 2009. Characterization of volatiles produced from Bacillus megaterium YFM 3.25 and their nematicidal activity against Meloidogyne incognita. Eur. J. Plant. Pathol., 26: 417-422.

Jonathan, E. I., Barker, K. R., Abdel-Alim, F. F., Vrain, T. C. and Dickson, D. W. 2000. Biological control of Meloidogyne incognita in tomato and banana with Rhizosphere, Actinomycetes and Pasteuria penetrans. Nematropica, 30: 231-240.

Jonathan, E. I., Cannayane, I. and Samiyappan, R. 2004. Field application of biocontrol agent for the management of spiral nematode, Helicotylenchus multicinctus in banana. Nematol. Mediterr., 32: 169-173.

Joshi, R. and Gardener, M. B. 2006. Identification of genes associated with pathogen inhibition in different strains B. subtilis. Phytopathol., 96: 145-154.

Karanja, N. K., Mutua, G. K. and Kimenju, J. W. 2007. Evaluating the effect of Bacillus and Rhizobium bioinoculant on nodulation and nematode control in Phaseolus vulgaris L. In: “Advances in Integrated Soil Fertility Research in Sub-Saharan Africa: Challenges and Opportunities",(Eds.): Bationo, A., Waswa, B., Kihara, J., and Kimetu, J. Springer, Netherlands, pp. 863-868.

Khalil, M. S. H., Allam, A. F. G. and Barakat, A. S. T. 2012. Nematicidal activity of some biopesticide agents and microorganisms against root-knot nematode on tomato plants under greenhouse conditions. J. Plant. Prot. Res., 52(1): 47-52.

Krebs, B., Hoeding, B., Kuebart, S., Workie, M. A., Junge, H., Schmiedeknecht, G., Grosch, R., Bochow, H. and Hevesi, M. 1998. Use of Bacillus subtilis as biocontrol agent. I: Activities and characterization of Bacillus subtilis strains. Zeitschrift Pflanzenkrankh Pflanzenschutz, 105: 181-197.

Lamberti, F., Tacconi, R., Marinari, A., Derrico, F. P. and Basile, M. 1987. Major plant parasitic nematodes associated with flower crops in Italy and their control. Difesa delta Pinate, 10: 77-84.

Mendoza, A. R., Kiewnick, S. and Sikora, R. A. 2008. In vitro activity of Bacillus firmus against the burrowing nematode Radopholus similis, the root-knot nematode Meloidogyne incognita and the stem nematode Ditylenchus dipsaci. Biocontrol. Sci. Techn., 18: 377-389.

Nagesh M. and Parvatha Reddy P. 1996. Management of Meloidogyne incognita on carnation and gerbera in commercial polyhouses. Pp. 249. In: Crop Productivity and Sustainability - Shaping the Future, 2nd International Crop Science Congress, 17-24, November, 1996, NAAS, New Delhi, India.

Nagesh, M. and Paravatha Reddy, P. 2000, Crop loss estimation in carnation and gerbera due to root-knot nematode 
Meloidogyne incognita (Kofoid and White) Chitwood, Pest. Manag. Hort. Ecosys., 6: 158-159.

Nagesh, M. and Parvatha Reddy, P.N. 2001. Pathogenicity of selected antagonistic soil fungi egg masses under in vitro and in vivo conditions. J. Bio Control, 15: 63-68.

Nico, A. I., Rafael, R. M., Jiménez-Daza, M. and Castillo, P. 2004. Control of root-knot nematodes by composted agro-industrial wastes in potting mixtures. Crop Prot., 23:581-587.

Niu, Q., Huang, X., Zhang, L., Lian, L., Li, Y., Li, J., Yang, J. and Zhang, K. 2007. Functional identification of the genebace16 from nematophagous bacterium Bacillus nematocida. Appl Microbiol Biotechnol, 75: 141-148.

Oka,Y., Chet, I. and Spiegel,Y. 1993. Control of the root knot nematode Meloidogyne javanica by Bacillus cereus. Biocontrol. Sci. Techn., 3: 115-126.

Salehi Jouzani, G. H., Seifinejad, A., Saeedizadeh, A., Nazarian, A., Yousefloo, M., Soheilivand, S., Mousivand, M., Jahangiri, R., Yazdani, M., Maali Amiri, R. and Akbari, S. 2008. Molecular detection of nematicidal crystalliferous Bacillus thuringiensis strains of Iran and evaluation of their toxicity on free-living and plant parasitic nematodes. Can. J. Microbiol., 54: 812-82.

Siddiqui Z. A. and Mahmood I. 1999. Role of bacteria in the manage-ment of plant parasitic nematodes: A review. Bioresource Technol., 69: 167-179.

Siddiqui, I. A. 2002. Suppression of Meloidogyne javanica by Pseudomonas aeruginosa and Bacillus subtilis in tomato. Nematol. Mediterr., 30: 125-130.

Siddiqui, M. R. 2000. Tylenchida Parasites of Plants and Insects. Second edition, CAB International, Wallingford, UK.

Siddiqui, Z. A., and Mahmood, I. 1993. Biological control of Meloidogyne incognita race 3 and Macrophominaphaseolina by Paecilomyceslilacinus and Bacillus sub- tilis alone and in combination on chickpea. Fund. Appl. Nematol., 16:215-218.

Singh, P. and Cameotra, S. S. 2004. Potential applications of microbial surfactants in biomedical sciences. Trends. Biotechnol., 22(3): 142-146.

Southey, J. F. 1986. Laboratory methods for work with plant and soil nematodes. Ministry of Agriculture, Fisheries and Food, Her Majesty's Stationary Office, London, UK.

Taylor, A. L. and Sasser, J. N. 1978. Biology, identification and control of root not nematodes (Meloidogyne spp). Coop publication, Department of Plant Pathology, North Carolina State University and U.S. Agency International Development, Raleigh, North Carolina, PP. 111.

Terefe, M., Tefera, T. and Sakhuja, P. K. 2009. Effect of a formulation of Bacillus firmus on root-knot nematode Meloidogyne incognita infestation and the growth of tomato plants in the greenhouse and nursery. $J$. Invertebr. Pathol., 100: 94-99.

Vidhyasekaran, P. and Muthamilan, M. 1999. Evaluation of powder formulation of Pseudomonas fluorescens Pf1 for control of rice sheath blight. Biocontrol. Sci. Techn., 9: $67-74$

Wei, J., Hale, K., Carta, L., Platzer, E., Wong, C., Fang, S., Aroian, V. 2003. Bacillus thurigiensis crystal proteins that target nematodes. Microbiol, 100: 2760-2765.

Weller, D. M., 1988. Biological control of soilborne plant pathogens in the rhizosphere with bacteria. Annu. Rev. Phytopathol., 26:379-407.

Whitehead, A. G., 1998. Plant nematode control. CAB International, Wallingford, UK, pp. 384.

Xia, Y., Xie, Sh., Ma, X., Wu, H., Wang, X., and Gao, X. 2011. The purl gene of Bacillus subtilis is associated with nematicidal activity. FEMS. Microbiol. Lett., 322: 99-107. 